\title{
Neurological manifestations in HTLV-1 patients with overactive bladder syndrome. A precursor of HAM/TSP?
}

\author{
Davi Costa ${ }^{1 *}$, André Muniz dos Santos ${ }^{2}$, Néviton Castro ${ }^{1}$, Isadora Siqueira ${ }^{1}$, Edgar Carvalho $^{1}$, Marshall Glesby ${ }^{1}$ \\ From 15th International Conference on Human Retroviruses: HTLV and Related Viruses \\ Leuven and Gembloux, Belgium. 5-8 June 2011
}

At least 20 million people are infected with HTLV-I virus in the world, and 3 to $5 \%$ develop the classical neurological or hematological manifestations of myelopathy (HAM/TSP) or T-cell leukemia (ATLL). HTLV-Iinfected patients with overactive bladder syndrome may represent $37 \%$. We studied 102 HTLV-1 positive individuals without HAM/TSP divided into two groups according to the presence or absence of overactive bladder $(\mathrm{OB})$ syndrome. Individuals with $\mathrm{OB}$ were more commonly female $(84.3 \%$ vs. $60.8 \%$ of asymptomatics, $\mathrm{P}$ $=0.01)$, but the mean age in the two groups was similar $(46.4 \pm 1.9$ vs. $42.3 \pm 1.7$ years, respectively; $\mathrm{P}=0.11)$. The prevalence of neurological complaints was higher in OB group, especially hand or foot numbness and arm or leg weakness. There was no difference between the groups in neurological strength and reflexes. Weakness remained strongly associated with $\mathrm{OB}$ in multivariate logistic regression analysis adjusting for sex and age (adjusted odds ratio and 95\% CI 3.59(1.45-8.88) in arms and 6.68(2.63-16.93) in legs). In summary, we have characterized a subgroup of HTLV-1 infected patients based on urinary complaints who have more frequent neurological symptoms compared to those without OB. Longitudinal studies are needed to determine if HTLV-1 associated $\mathrm{OB}$ is a precursor of HAM/TSP.

\section{Author details}

'Immunology, Universidade Federal da Bahia, Salvador, Bahia, Brazil.

${ }^{2}$ Infectious Diseases, Cornell Weill Scholl of Medicine, New York, NY, USA.

Published: 6 June 2011

* Correspondence: davi81@me.com

1 Immunology, Universidade Federal da Bahia, Salvador, Bahia, Brazil

Full list of author information is available at the end of the article
doi:10.1186/1742-4690-8-S1-A78

Cite this article as: Costa et al:: Neurological manifestations in HTLV-1 patients with overactive bladder syndrome. A precursor of HAM/TSP? Retrovirology 2011 8(Suppl 1):A78.
Submit your next manuscript to BioMed Central and take full advantage of:

- Convenient online submission

- Thorough peer review

- No space constraints or color figure charges

- Immediate publication on acceptance

- Inclusion in PubMed, CAS, Scopus and Google Scholar

- Research which is freely available for redistribution
C Biomed Central 